\title{
Åndedræt tegnsætning forsvinding
}

\section{- bemærkninger om Peer Hultbergs Requiem og kortprosasamlingen Slagne Veje.}

I.

Da Peer Hultberg efter 17 års litterær tavshed i 1985 udsendte Requiem, var der i såvel omfang som i ambition tale om et monumentalt værk. På trods af mere end 600 tekstsider og en almindelig opfattelse af, at bogen er en roman, kan Requiem dog ses som et eksperiment i den litterære kortform. Bogens 537 monologiske stemmer hverken samtaler eller aftegner et samlet narrativt forløb; snarere taler de for sig selv, som befandt de sig i 537 hermetisk lukkede rum. Alene dette forhold vanskeliggør en diskussion af Requiem som roman, og åbner for en læsning af den enkelte tekststemme frem for videre overvejelser af den store form.

For nylig sagde Peer Hultberg i et interview at „[Requiem] er tænkt vertikalt som en gigantisk søjle, tekst på tekst lagt oven på hinanden, og ideelt set forløber romanen på 2-3 minutter."1 Marianne Ping Huang griber i artiklen „Livløst gående Livfuldt gående" fat i ovenstående citat og omtaler følgende Requiem som "en svimlende perspektivisk forkortning af et billede af hele menneskemassen eller man kan forestille sig, at de 537 stemmer lyder simultant i en stor uhomogen brusen." 2 Dette betyder samtidig, at en læsning af romanen aldrig vil kunne gribe den ideelle modus, hvor alle tekster afvikles samtidigt. Kun oralt i et inferno af de 537 stemmer, som undervejs vil drukne i støj, kan dette realiseres.

Requiem er undfanget i denne utopiske stræben mod sublim sammensmeltning, en stræben kendetegnet ved sin uforløselighed. Den lukkede bog, hvor tekst ovenpå tekst viser det sublimes 
mulighed i profan gengivelse som en art gigantisk palimpsest, er samtidig det nærmeste en læsning kan komme koret af de 537 stemmer. Åbnes bogen brister muligheden for den læsning, hvor alle stemmer lyder samtidigt, og læsningen må snarere ses som en voldelig indtrængen, der ødelægger værket, en indtrængen, der ligner en beskrivelse i Barndom i Berlin omkring år 1900, hvor Walter Benjamin skriver:

At slå op i en af dem [bøgerne] havde ført mig lige ind i skødet, hvor det trak op til en urolig og formorket tekst, der gik svanger med farver. Der var sydende og flygtige farver, altid endte de med violet, der syntes at stamme fra det indre af et slagtedyr. ${ }^{3}$

For Benjamin fremstår læsning som sækulariseret slagtning, en opfattelse, der ligger langt fra eksempelvis den tyske romantiks tro på foreningen mellem værket og kritikken. Hvis bemægtigelsen af den store forms ideal Requiems ekstatiske forløsning på 180 sekunder aldrig kan realiseres gennem læsning, men altid allerede er umuliggjort ved åbningen af bogen, tvinges læseren til valget mellem enten at lægge værket fra sig eller betale den store forms forsvinden som pant for læsningen. I denne position byder den litterære detalje sig til i Hultbergs Requiem. En sådan detalje kunne være den korte form, en enkelt af bogens tekster. Jeg vil dog fokusere på et særligt karaktertræk ved den hultbergske kortform, nemlig den sproglige distribuering eller det sproglige antrit, hvormed teksten forløber, fordi netop udforskningen af det sproglige materiales mulighed synes intimt forbundet med formproblematikken; og derigennem kan der måske alligevel siges noget om Requiem som værk. Jeg vælger at læse tekst 5:

\section{5}

Vælge måtte man, man måtte vælge "du må vælge”, men hvad ville det sige at vælge, det absurdeste af begreber, stille et menneske krav om at vælge, æble eller pære, hindbær eller jordbær, abrikoser eller ferskner, bro-bro-brille og med tovtrækning bagefter, valgets dialektik, tovtrækning mellem to ligegyldige faktorer, neutraliserede netop fordi de var blevet opstillet som alternativer, havde de ikke været postuleret som alternativer havde de hver for sig haft værdi, hver for sig haft egen gyldighed, som sådan, for sig selv, hvilende i sig selv, men nu reduceredes de 
til blotte pinefulde alternativer som han måtte afvise, udelukkende fordi de var postulerede som alternativer "du må vælge", havde hun sagt "enten mig" eller hvad, enten-mig-eller-dig-eller-mig-eller-dig, enten mig eller din kone, enten mig eller dit arbejde, enten mig eller din mor, enten mig eller dit hus, enten mig eller dine børn "du må vælge", entenmig-eller-hindbær-eller-abrikoser-eller-jordbærsveskerfignerblommeræblerpærer "du må vælge for du må vælge", ,man må vælge”, ,, man kan ikke bare sådan ikke vælge man må vælge", og når han nu netop altid havde formået at arrangere det sådan at han kun befandt sig i situationer hvor han ikke behøvede at vælge, altid havde evnet at lægge sagerne sådan til rette at valget allerede på forhånd var truffet og at ethvert såkaldt valg derfor var et skinvalg, noget der var lige så absurd som valget mellem et æble og en pære, et hindbær og et jordbær "hvad vil du helst have", åh disse ulidelige spørgsmål, hvor han kun havde kunnet lukke øjnene og gribe for sig $\mathrm{i}$ blinde, fordi det var blevet ham ligegyldigt netop fordi det var blevet ham tilbudt som valg, var hun dog slet ikke klar over at med sit krav til ham om at vælge havde hun netop gjort det umuligt for ham at vælge hende, havde hun reduceret sig selv til en størrelse der var lige så uvæsentlig som et jordbær eller et hindbær, et æble eller en pære, havde hun dog blot forstået, havde hun dog blot vidst at ved at afæske ham et valg måtte han af nødvendighed enten vælge i blinde eller forsøge at lade status quo rinde videre og videre indtil spændingen mellem alternativerne var blevet så slap at den eneste form for valg blot kunne bestå i at forkaste alt og begynde forfra på en frisk, en frisk uden hende, men i stedet havde hun tvunget ham, forsøgt at tvinge ham, ved at opstille et alternativ, ved sit enten-eller, hun havde tvunget ham, og netop denne valgets tvang var hvad han aldrig havde kunnet underkaste sig, havde hun dog blot forstået at han aldrig valgte, rent principielt, at han blot tog det første det bedste af angst for at skulle vælge, og hvis det første ikke var det bedste ja så var det altså ikke det bedste og så var det andet heller ikke det bedste, mere var.der ikke at sige til det, i hvert fald havde han ikke måttet vælge, blot ikke vælge, så lad dog kun situationen mørnes og køre træt, spændingen mellem alternativerne slatnes indtil der hverken var alternativer eller spænding, blot ikke vælge, blot så forkaste, begynde forfra på en frisk, havde hun dog blot taget, og ikke givet ham valgets frihed." ${ }^{\prime 4}$

Requiems 536 øvrige tekster har omtrent samme længde og afvikles med samme sproglige antrit som femte tekst. I enkelte tekster er tegnsætningen endnu mere sparsom, mens ganske få har næsten normal grammatisk opbygning. Denne femte tekst forløber som én udstrakt sætning, som en kværnende gentagelsefigur af 
labyrintiske konstruktioner, hvor sætninger afbrydes og afledes, vender tilbage til tidligere afbrudte tekststumper, bliver til remse for en stund for igen at sætte af $i$ en ny retning, blot for endnu en gang at blive afbrudt af associationer, parodi eller parentetiske regibemærkninger. 5

Den sparsomme tegnsætning i denne ekspanderende tekstmasse sætter sine spor i læsningen. Tråden tabes undervejs, der må begyndes forfra, læses langsommere, måske endda læses højt. Requiems tekster og ikke mindst denne tekst er talte tekster og derfor vindes en hel del i såvel skønhed som forståelse ved at fremsige teksterne. Dette åbner samtidig for en af aflytning den særlige prosarytme, hvormed Hultbergs tekster forløber. Især gentagelsesfiguren slår rytmen an, en rytme, der formår at vriste teksten fri af den rest af narration, der trods alt kan anes under læsningen. Rytmen vender jeg tilbage til.

Kilden til den næsten maniske talestrøm af gentagelser, ophobninger og afbrydelser, som udgør teksten, kan føres tilbage til en eneste sætning: „du må vælge”. , „[D]u må vælge" er de tre ord som bliver ved med at hjemsøge fortællerens tanker og sætter et skred af bevidsthedstrømme igang. Strømmen af ord er næsten udelukkende associativ, og følgeligt lægger sætninger af uforenelig stilmæssig karakter sig i forlængelse af hinanden: „[...] æble eller pære, hindbær eller jordbær, abrikoser eller ferskner, bro-bro-brille og med tovtrækning bagefter, valgets dialektik, tovtrækning mellem to ligegyldige faktorer[...]". Opremsningen af frugter griber umærkeligt fat $\mathrm{i}$ først barnelegens diskurs og siden den filosofiske. Alle er de dog metonymiske forgreninger af „du må vælge”, og den korte tekst bliver derfor muligheds-betingelsen for den store. Det er fra denne tre-ords-irritation, som ikke vil gå væk, at teksten henter sin næring. Artikuleringen eller teksten, må derfor ses som forsøget på at tale sig fri af den lille tekst; og med det afsluttende ord 'frihed' når fortælleren frem til punktet før tavsheden. Internt i teksten fremstår friheden, dog som direkte forbundet med det paralyserende "du må vælge", en frihed fortælleren ikke ønsker. Som sidste ord før tavsheden afføder ordet 'frihed' imidlertid virkelig friheden, som den tager sig ud i teksten: talestrømmen standser. 
I Requiems afsluttende rammetekst postuleres en lignende frihed i opnåelsen af tavsheden og her for alle bogens stemmer: „Dagligt kommer de gående. Tavse gennem byen. Gående gennem byen. Tidløst gående. Ud til friheden. Til det nye liv. Hvilket herligt øjeblik. Til freden. Livfuldt gående. Gående." 6 Denne afsluttende del af Requiem står med sin insisterende brug af punktum og ekstremt korte sætninger i skarp kontrast til den næsten uendelige sætning, der udgjorde tekst 5. Artikuleringen og især kraften til at komme hinsides denne indtager det livfulde og rensende moment i Requiem, og de afsluttende ultrakorte sætninger er som de sidste svingninger før tavsheden helt omslutter personerne. Men selvom frihedstrangens arbejde i det sproglige materiale er uløseligt forbundet med form-problematikken i Requiem - bestræbelsen er netop tekstens ophør - synes tavsheden ikke for alvor at have sat sig igennem med denne 'livfulde' afslutning. For i kortprosa-samlingen Slagne veje fra 1988 radikaliserer Hultberg form-bestræbelsen i et omfang, der taler for såvel en videreførsel som en afvisning af projektet i Requiem.

II.

Bogomslaget til Slagne veje $e^{7}$ viser Kodak-filmstrimler, hvori små farverige negativer kan anes. Mellem strimlerne er seks rækker af bogstaver, der ikke synes at indgå i nogen synderlig orden. Åbnes bogen således, at hele omslaget er synligt, træder en lille tekst imidlertid langsomt frem af den sammenpressede bogstavvrimmel: „menjegha/rdetimo/ddigatduh/arforlad/tdinførst/ ekærlighed" - En smule luft mellem ordene letter læsningen betydeligt: 'men jeg har det imod dig at du har forladt din første 'kærlighed'; og selvom Hultberg doserer rigeligt med luft mellem sine ord i såvel de 40 korte beretninger, der udgør bogens første del, som i de seks enetaler, der afslutter bogen, så rejser betydelige problemer sig i læsningen af Slagne veje, problemer af såvel fortolkningsmæssig som af fysiologisk art.

Blot en hastig bladren i Slagne veje er nok til at rejse overvejelser omkring bogens komposition. De 40 indledende beretninger er ultrakorte tekster på en til halvanden tekstside, der med en- 
kelte undtagelser søger at indramme et individs liv fra fødsel til død, især springer den store kredsen om selvmord i øjnene. Overfor disse beretninger står de seks enetaler, alle med den overordnede titel „Men jeg har det imod dig at du har forladt din første kærlighed". Som tekst 5 i Requiem afvikles disse enetaler som én sætning. De er dog betydeligt længere og udgør hver især omkring ti sider. Alle er de tværsnit af den erindrende bevidsthed, hvilket hos Hultberg åbner for en næsten febril hastighed, konstant brug af fokalisationsskift og en sammenfletning af løsrevne tekststumper. Allerede i så kort en beskrivelse anes Slagne vejes stramme komposition mellem det enkelte liv fastholdt som koncentrat i de 40 beretninger og forsøget på gennem enetalernes udstrakte kværnen at komme fri af det erindrende nu. De korte beretninger adskiller sig som sagt væsentligst fra stykkerne i Requiem og peger med deres præg af krønike snarere fremad i forfatterskabet, hvor de i udviklet form blev til den roman $i$ hundrede tekster, der kom til at hedde Byen og verden. De seks enetalers åbentlyse slægtskab med Requiems tekster betyder med andre ord, at Slagne veje aftegner et skift i Hultbergs forfatterskab. Alene af den grund er det værd at undersøge kompositionen i Slagne veje og især, hvordan bogens væsensforskellige, formmæssige bestræbelser alle forskelle til trods alligevel berører hinanden.

De 40 beretninger er korte og næsten klassisk narrative og er alle konstrueret med en prægnant afsluttende sætning. Disse pointerede sætninger er ofte perfide eller sarkastiske og afføder små chok af omslag i læsningen. Et eksempel er tekst XXI, der beskriver en ældre mands forhold til sin noget yngre kone. Efter en bjergbestigning, hvor han måtte opgive halvvejs med svimmelhedsanfald, slutter teksten:

Hun var forstående, men jo mere forstående hun var des grusommere blev hævnen. Og da han forlod hende efter mindre end et år havde han den triumf at folk tog dem for jævnaldrende. 8

Hvor overraskende denne sætning end er som afslutning på en iøvrigt udramatisk tekst, synes der alligevel bygget op til netop 
dette brud - såvel det tematiserede brud som det brud, der afbryder narrationen og i ét nu koncentrerer hele tekstens forløb om omslaget og afbrydelsen. Afbrydelse findes i stort set alle 40 beretninger, mest åbentlyst i de tekster, der slutter med døden. Det er dog især i de 13 tekster, hvor der kredses om selvmord, at berøringspunktet til Slagne vejes seks enetaler bliver tydelig.

Som sagf forløber hver af disse enetaler over ti sider uden punktum, blot en lang strøm af bevidsthedens forsøg på at komme fri af et bestemt moment gennem en vedholdende og erindrende insisteren. Talerne er udmattende og svimlende på samme tid, fordi der ikke undes læseren det pusterum eller det overblik som et simpelt punktum eller blot et semikolon kan give; og fordi sætninger afbrydes og afledes inden fuldbyrdelsen i en tekst næsten uden tegnsætning, umuliggøres en naturlig læserytme. Talerne Non omnis moriar og Spilleregler er de mest radikale videreførelser af sporet fra Requiem. Spilleregler er en ældre mands erindring om forholdet til sin far og sin søn-alt sammen fremkaldt af et spil kroket:

Hvis dog blot han ville lade være med at gøre det, "men så lad da være med at gøre det" havde hans mor sagt, og han havde hævet køllen og han havde ladet den falde, og det var på skrømt ville han blot være ekstra sikker på at ramme rigtigt, tog han sigte og sigte, sigtede han igen og igen, og den gik op og ned gjorde køllen langsomt og langsomt og så troede han pludselig den ville ramme og så standsede den blot, "men så lad dog være" sagde hans mor, men en dreng må lære, for en dreng må lære realiteterne at kende, og det er en fars opgave og det er en fars pligt at lære sin søn realiteterne at kende, og har han gjort en fejl, for han havde gjort den fejl at lade sig ramme af sin fars kugle, havde han gjort en fejl måtte han tage skade for hjemgæld som det hedder, han har gjort en fejl hvor lille han så end er, og det må han lære også selvom han kun er syv og hvis han vil spille med de voksne, og de voksne havde stået omkring dem "men så lad da være med at gøre det det er synd for drengen", og de havde alle set til og kollen havde hævet sig og nu og nu og nu troede han at den ramte kuglen [...]

[...], Rom den evige stad, bare navnet, og hans kusine havde fniset og så var hun blevet bange, for de vokse de tog det så alvorligt, og de begyndte at skændes, ligefrem skændes, og hans mor havde sagt igen og igen "men så lad da være med at gøre det, og hans far havde sat køllen og så taget den igen, og så havde han støttet sig til køllen, og hans ku- 
sine havde røde sløjfer i sine rottehaler, knaldrøde, og havde hun ikke haft en grøn kjole på, og det var kun de andre der havde ægget ham til det og tvunget ham til det og han havde kun trukket ganske let men alligevel skreg hun op og skreg hun op og hun løb ind til sin mor og i virkeligheden havde han allerhelst strøget hende over fletningerne, og hendes mor havde ikke rigtig skændt på ham for hun var jo ikke hans mor han var barn af en anden mor men hun havde fortalt det til hans mor og han havde forklaret og hun havde troet hans mor havde troet, og hans kusine havde skjult sig bag hans mor og så bag hans far, "for en dreng må lære", og hans søn skal lære, der er regler og der er regler i livet og der er regler i spil og man må lære at hvis man bryder regler og hvis man gør noget forkert så må man tage skade for hjemgæld og kuglerne var stødt sammen og han skulle tage skade for hjemgæld, og alle tog skade for hjemgæld og hans far tog skade for hjemgæld og hans mor tog skade for hjemgæld, og dengang havde plænen været så grøn så grøn $[. . .]^{9}$

Tekststumper som 'men så lad dog være med at gøre det', 'en dreng må lære', 'der er noget der hedder skade og der er noget der hedder hjemgæld', eller 'havde set køllen hæve sig og sænke sig' introduceres alle på Spillereglers to første sider og dukker siden konstant op i forskellige konstellationer. Undervejs i teksten afløses disse af andre tekststumper, men gentagelsesfiguren forbliver intakt. I en tekst, hvor synsvinklerne skifter igen og igen (ordet 'han' omfatter hele seks personer), og hvor tegnsætningen sine steder udebliver over en halv tekstside, bliver læsningen først og fremmest et spørgsmål om at finde fodfæste i teksten. I denne position bliver de konstant gentagne tekststumper undervejs til oaser af genkendelse. Tekstens umådelige bevidsthedsstrøm skal derfor ikke læses som et sprogligt amokløb, der kunne friste til psykoanalytiske overvejelser. Snarere er talerne prætekster før en tegnsætnings inddæmning. Det er i dette perspektiv at repetitionen af tekststumperne bliver vigtig. Akkurat som ordene 'du må vælge' i Requiems femte tekst holder sammen på teksten og betinger dens ophør, nærmer de konstant gentagne tekststumper i Spilleregler sig et omslagspunkt, hvor deres betydning træder $\mathrm{i}$ baggrunden, men hvor de som sætninger begynder at fremstå som orienteringspunkter i såvel læsningens som åndedrættets tjeneste. 
Jeg har tidligere berørt såvel Requiems som Slagne vejes yderst sparsomme tegnsætning og de såvel læserytmiske som forståelsesmæssige problemer dette medfører. Når dele af sætninger begynder at antage funktion af orienteringspunkt eller sætningstegn i Spilleregler åbnes ikke blot for et større overblik i en nærmest ulæselig tekst, men der introduceres en anden læserytme, en læserytme, som mere nøjagtigt kan indramme tekstens ekspanderende prosabevægelse. For udover, at disse sætninger giver plads til åndedrættet, genspejler de i deres konstante repetition den spiralfigur, hvori teksten forløber. Omslaget fra sætningsstumper til en art sætningstegn er dog ikke en redning af teksten. Snarere skal det ses som symptom på en drift mod ophoret, mod udmattelse i skriften, der kendetegner alle seks taler. Men det katharsiske moment, der kunne findes som postulat i Requiem mister sin troværdighed i enetalernes monstrøse kværnen; det er snarere kvælende end livfuldt. Ved igen og igen at tvinge gentagelsesfiguren til nye selvkonfrontationer ender talerne i en position, hvor selvdestruktionen i sig selv bliver drivkraften.

Som samlet konstruktion indtager Slagne veje med sin udstrakte sproglige afsøgning $i$ enetalerne og kredsen om det punktuelle i de 40 beretninger (hvormed det narrative også her træder $i$ baggrunden) en særegen avantgardistisk position. Med udgivelsen af såvel Præludier (1991) som Byen og verden (1992) vinder fortælligen og den narrative suspense terræn i Hultbergs forfatterskab, selvom afbrydelse, ophobning og gentagelse stadig udgør kernen i disse romaner; også de udgøres af kortprosa.

I Requiems monologer og især i Slagne vejes enetaler fremstår den korte prosa som tekster, der ikke ønsker at bestå, men gennem sine udmattelsesfigurer konstant søger at fravriste skriften dens grammatiske binding. Præcis i dette moment af omslag, som er tekstens forsvindingspunkt, affødes en anden erfaring. Denne erfaring er radikalt kropslig og afsættes, hvor grammatik, læsning, skrift og fysisk formåen konfronteres. For i Hultbergs enetaler standser de ti siders uafbrudte tekstkværnen kun tilsyneladende med et punktum: umærkeligt gives stafetten videre, og hovedpinen bliver manifest. 


\section{Noter}

1. Jeg henviser til mit interview „I romanens rum" i Standart 1, 1996.

2. Marianne Ping Huang "Livløst gående Livfuldt gående", in Tidens former, Æstetikstudier IV, p. 124. Århus 1997.

3. Walter Benjamin Barndom i Berlin omkring år 1900, pp. 30-31. Rævens Sorte Bibliotek, Viborg 1992.

4. Peer Hultberg, Requiem, 1985.

5. Marianne Ping Huang beskriver i "Livløst gående Livfuldt gående” Hultbergs stil med følgende begreber: asyndese (ophobning eller remse), anakoluti (afbrydelse eller forkortning) og anafor (gentagelse)

6. Requiem p. 611.

7. Peer Hultberg Slagne Veje, 1988.

8. ibid. p. 44.

9. ibid. p. 129 og p. 130. 